\title{
Efficiencies of Nitrogen Removal in Slope-Constructed Wetlands
}

\author{
Guofen Hua ${ }^{1 *}$, Jinli Li ${ }^{1}$, Ying Cheng', Jun Kong², Xiangdong Liu', \\ Ying Shi', Yuying Huang ${ }^{1}$
}

${ }^{1}$ College of Water Conservancy and Hydroelectric Power, Hohai University, Nanjing, 210098, P.R. China

${ }^{2}$ College of Harbour, Coastal and Offshore Engineering, Hohai University, Nanjing, 210098, P.R. China

Received: 24 July 2020

Accepted: 26 September 2020

\begin{abstract}
This study proposes a slope-constructed wetland that can be adapted to local conditions in combination with landscape changes along with topography, and the influences of slope and hydraulic load condition changes on nitrogen removal were explored. The main results were as follows. (1) The slope-constructed wetlands showed good feasibility. The removal rate of ammonia nitrogen was approximately $76.60 \%-77.79 \%$, the removal rate of nitrate nitrogen was $54.46 \%-56.87 \%$, and the removal rate of total nitrogen was approximately $74.68 \%-77.16 \%$. (2) Different slopes had their own advantages in removing different forms of nitrogen. The steeper the slope was, the higher the removal of ammonia nitrogen but the lower the removal of nitrate nitrogen. This finding was mainly because with slope changes, the proportion of saturated and unsaturated areas in the slope-constructed wetland changed, and therefore, the ratio in the nitrification zone and denitrification zone subsequently changed; eventually, the removal efficiencies of ammonia nitrogen and nitrate nitrogen were affected.
\end{abstract}

Keywords: slope constructed wetland, nitrogen removal, slope changes, saturated zone and unsaturated zone

\section{Introduction}

Currently, numerous studies have focused on the design, development and performance of Constructed Wetlands (CWs), and it was also reported that CWs could be efficient for removing various pollutants (organic matter, nutrients, trace elements, contaminants, pathogens, etc.) from wastewater [1-3].

The oxygen-rich conditions inside the bed matrix of vertical-flow wetlands support nitrification [4]. On the

*e-mail: huaguofen2005@126.com other hand, the anaerobic conditions of horizontal-flow wetlands trigger denitrification, which is the last step of classic nitrogen removal [5]. Due to such contradictory environmental requirements, achieving simultaneous nitrification and denitrification rates in a single verticalflow or horizontal-flow wetland unit is extremely difficult. For this reason, nitrogen removal efficiency is not as expected.

At present, there are several methods to improve the removal rate of nitrogen: artificial aeration [6], tidal operation [7], step feeding [8-9], external carbon addition, microbial augmentation, the allocation of various plants and the combination of various substrates [10-11]. However, improvements in nitrogen removal 
are still limited, mainly due to the lack of favorable alternate aerobic anaerobic conditions for nitrification and denitrification. Because nitrification is a two-step process, inorganic ammonium nitrogen is oxidized to nitrite nitrogen by a bacterial group that is commonly referred to as Nitrosomonas [12]. This group functions in anoxic-anaerobic environments and in the presence of facultative biomass [13-14].

Creating appropriate alternating aerobic and anaerobic conditions in $\mathrm{CWs}$ is required to improve nitrogen removal. In this study, we attempted to construct a sloped wetland that provided alternating aerobic and anaerobic conditions with different slopes to improve nitrogen removal. This study is useful for better understanding the complicated $\mathrm{N}$ removal process in CWs.

\section{Materials and Methods}

\section{System Description and Operation}

Three laboratory-scale parallel slope-constructed wetlands made of polymethyl methacrylate that were $100 \mathrm{~cm}$ in height, $100 \mathrm{~cm}$ in length and $30 \mathrm{~cm}$ in width were operated under different conditions, as shown in Fig. 1.

The water outlet was set at the bottom left of the rectangular wetland model, and two elevators were placed under the right side of the wetland model to adjust the slope of the reactor.

At the cross section $80 \mathrm{~cm}$ (group A), $60 \mathrm{~cm}$ (group B), $40 \mathrm{~cm}$ (group C) and $20 \mathrm{~cm}$ (group D) from the exit, four sampling needles with lengths of $10 \mathrm{~cm}$, $20 \mathrm{~cm}, 30 \mathrm{~cm}$ and $40 \mathrm{~cm}$ were buried (group A, for example, named A10, A30, A50 and A70). During the experimental process, water samples were extracted with a needle; then, the extracted water samples were collected in a $100 \mathrm{ml}$ sampling bottle, and the dissolved
Table 1 . Wastewater quality characteristic.

\begin{tabular}{|c|c|c|c|}
\hline Index & $\mathrm{NH}_{4}^{+}-\mathrm{N}$ & $\mathrm{NO}_{3}-\mathrm{N}$ & $\mathrm{TN}$ \\
\hline Concentration $(\mathrm{mg} / \mathrm{L})$ & $33.1-45.8$ & $16.0-22.8$ & $42.2-59.1$ \\
\hline
\end{tabular}

oxygen (DO) concentration was measured in the field with a portable multiparameter water quality tester (YSI Inc., 556-01 Multiparameter Meter, Handheld, Submersible, USA).

When the cattails in the wetland system were planted, the reactor was operated for one month to allow the plants and microorganisms to adapt and grow. After the system stabilized, the experiment began.

Referring to the initial rainstorm runoff concentration in China [15], simulated rainwater was used as the experimental water, and glucose, $\mathrm{NH}_{4} \mathrm{Cl}$, $\mathrm{KNO}_{3}, \mathrm{KH}_{2} \mathrm{PO}_{4}$ and a small amount of other trace elements were added into the tap water to make artificial sewage. The simulated wastewater concentrations are described in Table 1.

The operation time was from April 2018 to October 2018. The water inflow was $100 \mathrm{~L}$, and the intermittent operation mode was adopted. The hydraulic loads were $1000 \mathrm{~mm} / \mathrm{d}$ and $500 \mathrm{~mm} / \mathrm{d}$, respectively. Each hydraulic load experiment was conducted under three slope conditions of $5^{\circ}, 10^{\circ}$ and $15^{\circ}$ referenced by Liao et al [16]. At the beginning of the experiment, two elevators were rotated to make the slope of the reactor reach the preset slope. The simulated sewage was prepared with tap water in a $100 \mathrm{~L}$ bucket according to the inlet water quality. The outflow was controlled with a water stop clamp so that the water in the wetland unit could flow out in time period $\mathrm{T}$. Then, four interval time points were set by using a timer for periods of time (T), as shown in Table 2. If $\mathrm{T}=6.5 \mathrm{~h}$, then the five time points were $0.5 \mathrm{~h}, 2.5 \mathrm{~h}, 4.5 \mathrm{~h}$ and $6.5 \mathrm{~h}$; if $\mathrm{T}=13.5 \mathrm{~h}$, then the five time points were $1.5 \mathrm{~h}, 5.5 \mathrm{~h}, 9.5 \mathrm{~h}$ and $13.5 \mathrm{~h}$.

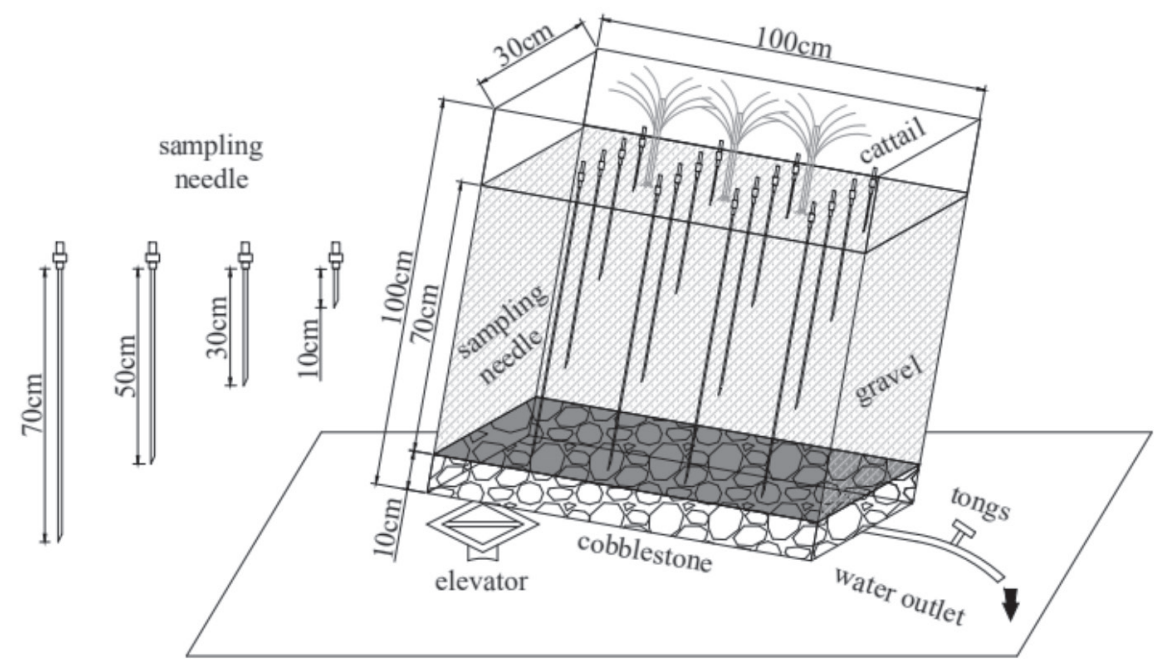

Fig. 1. Schematic diagram of the slope-constructed wetlands. 
Table 2. The four interval time points during periods of time (T).

\begin{tabular}{|c|c|c|c|c|}
\hline $\mathrm{T}$ & $\mathrm{T} 1$ & $\mathrm{~T} 2$ & $\mathrm{~T} 3$ & $\mathrm{~T} 4$ \\
\hline $\mathrm{T}=6.5 \mathrm{~h}$ & $0.5 \mathrm{~h}$ & $2.5 \mathrm{~h}$ & $4.5 \mathrm{~h}$ & $6.5 \mathrm{~h}$ \\
\hline $\mathrm{T}=13.5 \mathrm{~h}$ & $1.5 \mathrm{~h}$ & $5.5 \mathrm{~h}$ & $9.5 \mathrm{~h}$ & $13.5 \mathrm{~h}$ \\
\hline
\end{tabular}

During the beginning of the experiment (taking the cross-section of group A as an example, and with the other cross-sections remaining the same), at the first time point (T1), water samples were taken from the $10 \mathrm{~cm}$ needle tube (A10) of group A and placed in a sampling bottle marked A10-1 (water samples were taken from A10 at the first T1). The same was done for groups B, C and D. Next, water samples were taken from the $30 \mathrm{~cm}$ needle tube (A30) of group A and placed in a sampling bottle marked A30-1. Then, water samples were taken from the $50 \mathrm{~cm}$ needle tube (A50) of group A and placed in a sampling bottle marked A50-1. Finally, water samples were taken from the $70 \mathrm{~cm}$ needle tube (A70) of group A and placed in a sampling bottle marked A70-1. The same procedure was applied for the B, C and D samples. At time T2, due to the decrease in the water surface in the reactor, the water samples could not be extracted from the $10 \mathrm{~cm}$ needle tube. Therefore, we began the sampling with the $30 \mathrm{~cm}$ needle tube; the water sample was then placed in a sampling bottle and labeled A30-2 (water samples were taken from $\mathrm{A} 30$ at the first $\mathrm{T} 2$ ); the procedure was applied to the $50 \mathrm{~cm}$ and $70 \mathrm{~cm}$ groups as well. At time T3, similarly, water samples could not be extracted with the $30 \mathrm{~cm}$ needle. Therefore, we began the sampling with the $50 \mathrm{~cm}$ needle tube and then placed the water samples into a sampling bottle labeled A50-3 (water samples were taken from A50 at the first T3); the $70 \mathrm{~cm}$ group was similar. At time T4, only water from the $70 \mathrm{~cm}$ group could be extracted; we put the water samples in a sampling bottle labeled A70-4 (water samples were taken from A70 at the first T4). At time $\mathrm{T} 5$, water samples were collected with sampling bottles at the outlet.

\section{Sample Collection and Analytical Methods}

All water samples were analyzed and measured in the laboratory for $\mathrm{NH}_{4}^{+}-\mathrm{N}, \mathrm{NO}_{3}^{-}-\mathrm{N}$ and $\mathrm{TN}$ according to Professional Standards Compilation Group of People's Republic of China. The dissolved oxygen concentration was measured with a YSI ProPlus.

\section{Calculation of the Nitrification Rate and Denitrification Rate}

In this study, to determine the nitrification rate at each time period, the minimum nitrification rate was considered; it was assumed that the mechanisms of volatilization, adsorption, biomass accumulation and other denitrification mechanisms could be ignored [17-18].

$$
\begin{aligned}
& \mathrm{NR}=\left(\mathrm{C}_{\text {NH4-N Effluent }}-\mathrm{C}_{\text {NH4-N Influent }}\right) / \mathrm{t} \\
& \mathrm{DR}=\left(\mathrm{C}_{\text {NO3-N Effluent }}-\mathrm{C}_{\text {NO3-N Influent }}\right) / \mathrm{t}
\end{aligned}
$$

Equations 1 and 2 were based on the research results of Gonzalo et al. [17], where NR denotes the nitrification rate in $\mathrm{mg} /(\mathrm{L} \cdot \mathrm{h}), \mathrm{C}_{\mathrm{NH} 4-\mathrm{N}}$ Effluent denotes the concentration of $\mathrm{NH}_{4}^{+}-\mathrm{N}$ sampled at the end of time period $\mathrm{t}$ in $\mathrm{mg} / \mathrm{L}$, and $\mathrm{C}_{\mathrm{NH} 4-\mathrm{N} \text { Influent }}$ denotes the average concentration of $\mathrm{NH}_{4}^{+}-\mathrm{N}$ sampled at the beginning of time period $\mathrm{t}$ in $\mathrm{mg} / \mathrm{L}$.

DR denotes the denitrification rate in $\mathrm{mg} /(\mathrm{L} \cdot \mathrm{h})$, $\mathrm{C}_{\text {NO3-N Effluent }}$ denotes the $\mathrm{NO}_{3}^{-}-\mathrm{N}$ concentration sampled at the end of time period $\mathrm{t}$ in $\mathrm{mg} / \mathrm{L}$, and $\mathrm{C}_{\mathrm{NO} 3-\mathrm{N} \text { Influent }}$ denotes the average $\mathrm{NO}_{3}^{-}-\mathrm{N}$ concentration sampled at the beginning of time period $\mathrm{t}$ in $\mathrm{mg} / \mathrm{L}$.

\section{Removal Rates of All Forms of Nitrogen}

$$
\eta(\%)=\left(\mathrm{L}_{\mathrm{i}}-\mathrm{L}_{\mathrm{e}} / \mathrm{L}_{\mathrm{i}}\right) \cdot 100
$$

In equation $3, \mathrm{~L}_{\mathrm{i}}$ is the concentration load of the inlet water in $\mathrm{g} /\left(\mathrm{m}^{2} \cdot \mathrm{d}\right)$ and $\mathrm{L}_{\mathrm{e}}$ is the concentration load of the outlet water in $\mathrm{g} /\left(\mathrm{m}^{2} \cdot \mathrm{d}\right)$.

$\mathrm{L}_{\mathrm{i}}$ and $\mathrm{L}_{\mathrm{e}}$ were calculated with equations 4 and 5 , respectively, where $\mathrm{C}_{i}$ is the pollution concentration of the inlet water in $\mathrm{g} / \mathrm{m}^{3}, \mathrm{C}_{\mathrm{e}}$ is the pollution concentration of the outlet water in $\mathrm{g} / \mathrm{m}^{3}, \mathrm{Q}_{\mathrm{i}}$ is the inlet velocity in $\mathrm{m}^{3} / \mathrm{d}, \mathrm{Q}_{\mathrm{e}}$ is the outlet velocity in $\mathrm{m}^{3} / \mathrm{d}$, and $\mathrm{A}$ is the bed surface area in $\mathrm{m}^{2}$ :

$$
\begin{aligned}
& \mathrm{L}_{\mathrm{i}}=\mathrm{C}_{\mathrm{i}} \cdot \mathrm{Q}_{\mathrm{i}} / \mathrm{A} \\
& \mathrm{L}_{\mathrm{e}}=\mathrm{C}_{\mathrm{e}} \cdot \mathrm{Q}_{\mathrm{e}} / \mathrm{A}
\end{aligned}
$$

Statistical Analysis

All statistical analyses were performed with the software SPSS 22.0. The method of parameter test was used to analyze the removal of various forms of nitrogen in slope constructed wetland. Variation in the nitrification rates and denitrification rates with depth were examined using one-way analysis of variance (ANOVA), and Pearson's correlation was used to test the relationships between nitrification rates and denitrification rates.

\section{Results and Discussion}

\section{Removal of Various Forms of Nitrogen in Slope-Constructed Wetlands}

As shown in Fig. 2, the removal rate of ammonia nitrogen was approximately $76.60 \%-77.79 \%$, the removal rate of nitrate nitrogen was $54.46 \%-56.87 \%$, and the removal rate of total nitrogen was approximately $74.68 \%-77.16 \%$. 


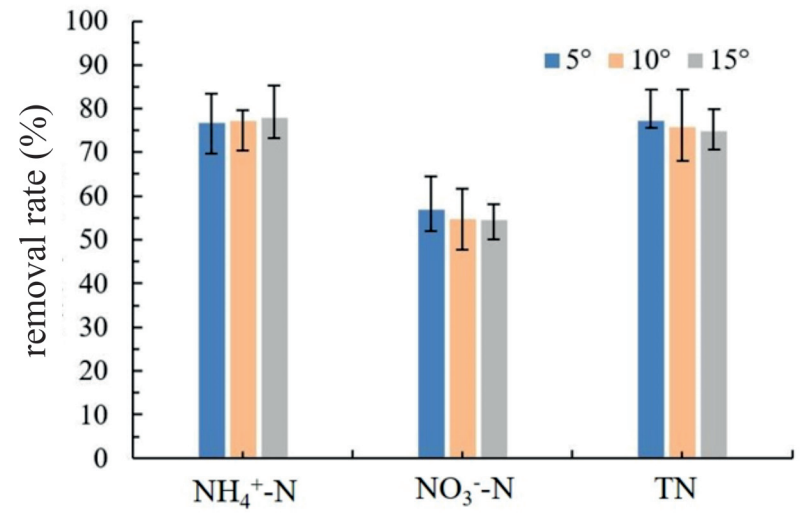

Fig. 2. Removal rates of $\mathrm{NH}_{4}^{+}-\mathrm{N}, \mathrm{NO}_{3}^{-}-\mathrm{N}$ and $\mathrm{TN}$ in the slopeconstructed wetlands under different slope conditions.

Slope had different influences on the removal of different forms of $\mathrm{N}$. The higher the slope was, the higher the removal rate of ammonia nitrogen and the lower the removal rate of nitrate nitrogen. Under the same slope, the removal rate of $\mathrm{NO}_{3}^{-}-\mathrm{N}$ was significantly different from that of $\mathrm{NH}_{4}^{+}-\mathrm{N}$ and $\mathrm{TN}(\mathrm{P}<0.05)$; specifically, the removal rate of $\mathrm{NH}_{4}^{+}-\mathrm{N}$ and $\mathrm{TN}$ was significantly higher than that of $\mathrm{NO}_{3}^{-}-\mathrm{N}$. However, the removal rates of $\mathrm{NH}_{4}^{+}-\mathrm{N}, \mathrm{NO}_{3}^{-}-\mathrm{N}$ and $\mathrm{TN}$ showed no significant difference among the three types $(\mathrm{P}>0.05)$.
The Concentration Distributions of Ammonia Nitrogen in the Slope-Constructed Wetlands

Fig. 3 shows the ammonia nitrogen concentration variation in the slope-constructed wetlands at $5^{\circ}$. And figures of ammonia nitrogen concentration variation at $10^{\circ}$ and $15^{\circ}$ were provided in the appendix (supplementary Fig. 1). The ammonia nitrogen concentration decreased with decreasing depth, but the gaps in the reduction were narrowing because the DO concentration decreased, and ammoniation decreased [19].

The Concentration Distributions of Nitrate Nitrogen in the Slope-Constructed Wetlands

Fig. 4 shows the nitrate nitrogen concentration variation in the slope-constructed wetlands at $5^{\circ}$. And figures of nitrate nitrogen concentration variation at $10^{\circ}$ and $15^{\circ}$ were provided in the appendix (supplementary Fig. 2). The content of nitrate decreased along the direction of water flow and gradually decreased with depth. This finding was because denitrification becomes increasingly stronger as the concentration of nitrate changes with water flow and depth [20].

An interesting point is that at the same slope, as the DO value decreased over time, the saturated
$\mathrm{T}=0.5 \mathrm{~h}$

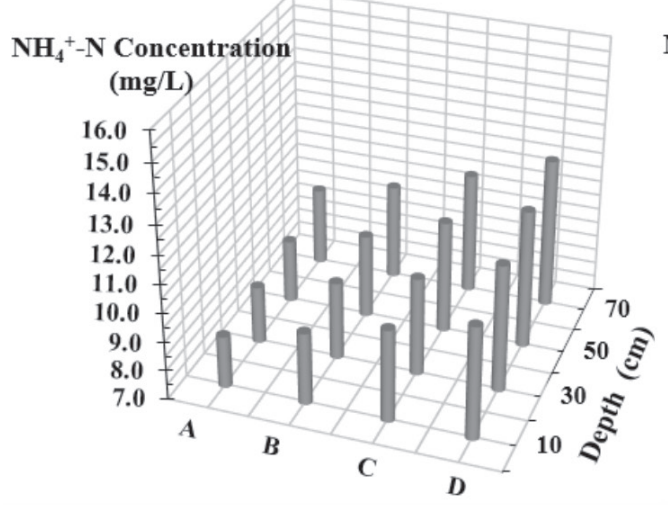

$\mathrm{T}=4.5 \mathrm{~h}$

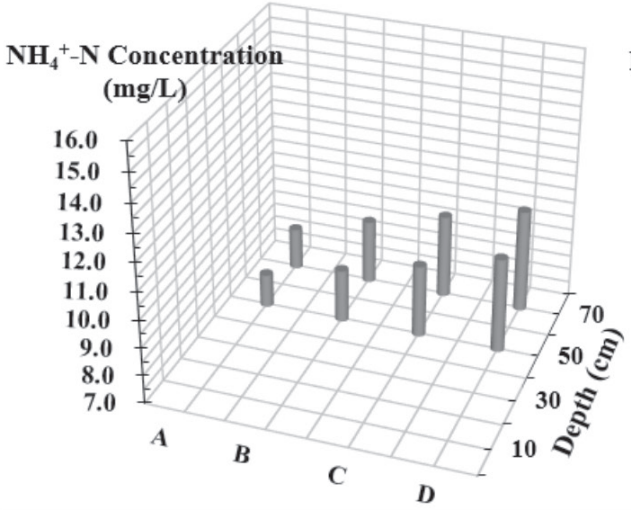

$\mathrm{T}=2.5 \mathrm{~h}$

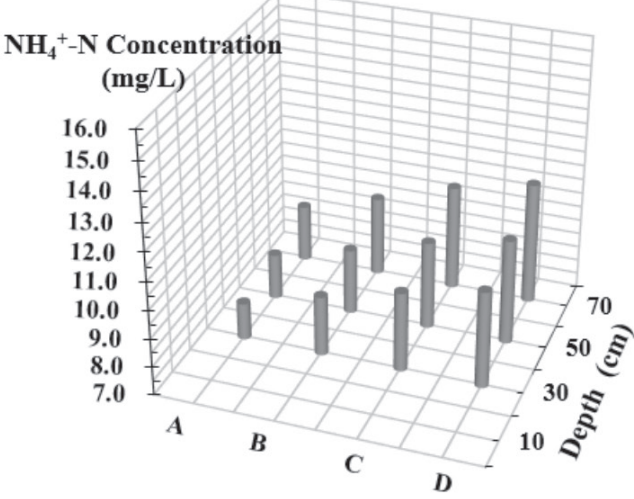

$\mathrm{T}=6.5 \mathrm{~h}$

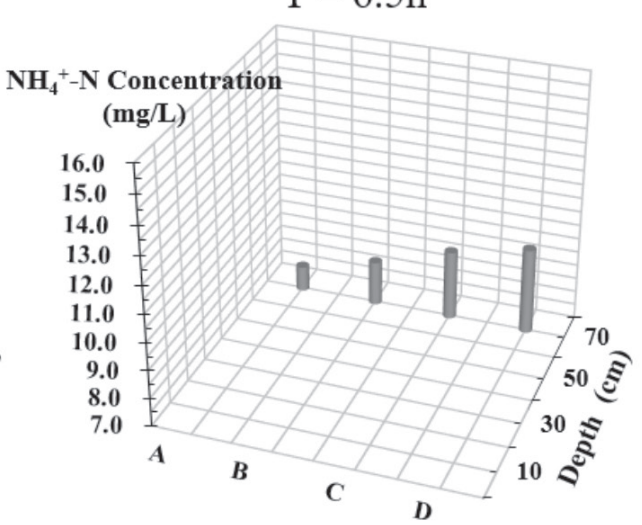

Fig. 3. Ammonia nitrogen concentration of the plant group in $5^{\circ}$. 
$\mathrm{T}=0.5 \mathrm{~h}$

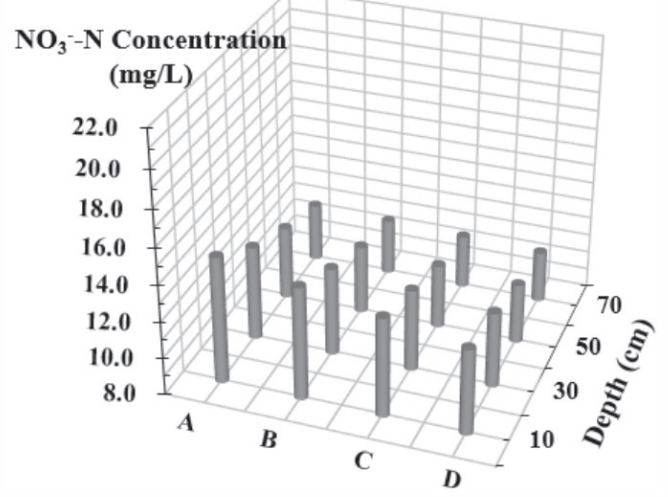

$\mathrm{T}=4.5 \mathrm{~h}$

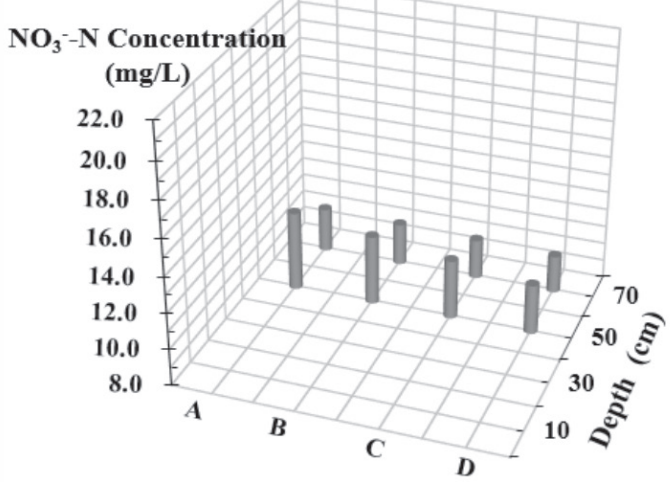

Fig. 4. Nitrate nitrogen concentration of the plant group in $5^{\circ}$.
$\mathrm{T}=2.5 \mathrm{~h}$

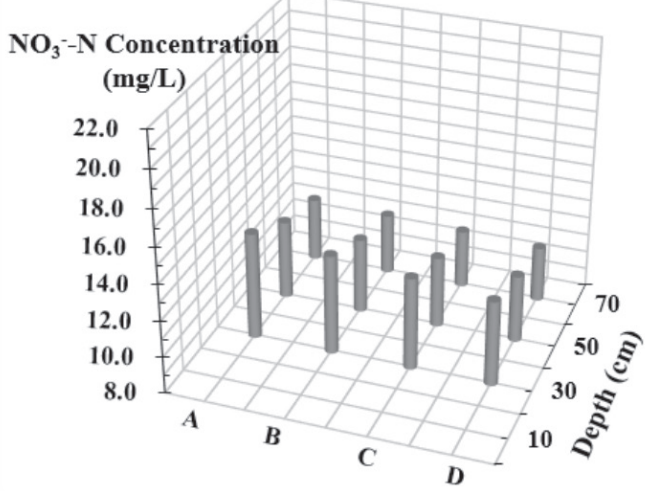

$\mathrm{T}=6.5 \mathrm{~h}$

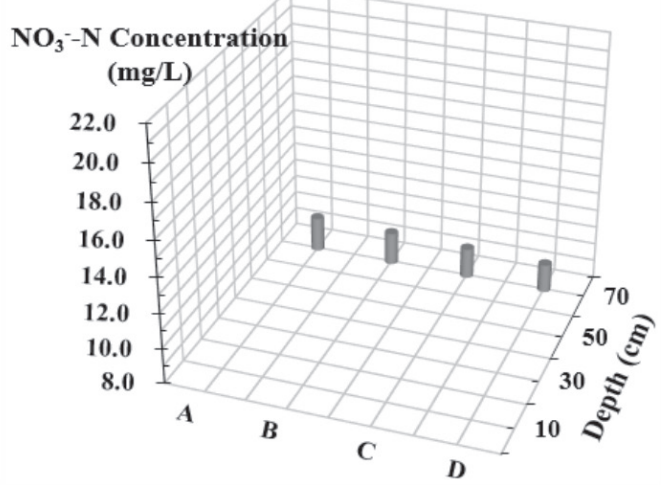

$\mathrm{T}=0.5 \mathrm{~h}$

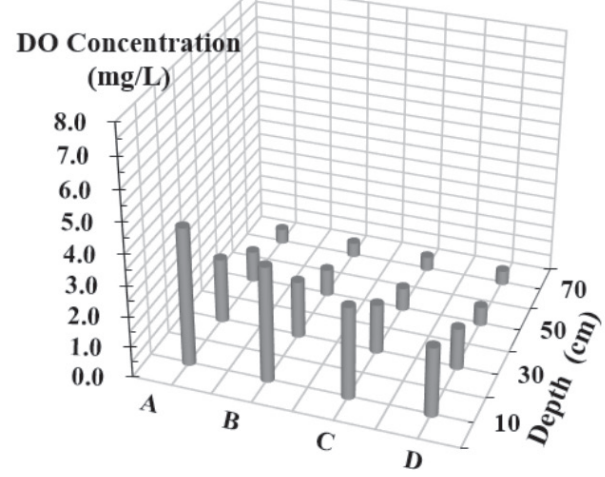

$\mathrm{T}=4.5 \mathrm{~h}$

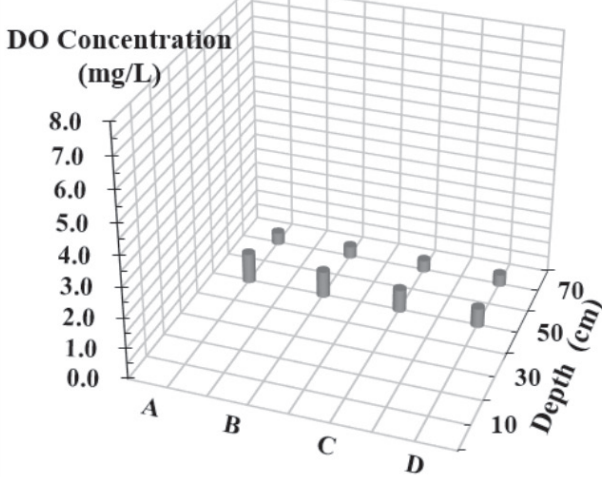

$\mathrm{T}=2.5 \mathrm{~h}$

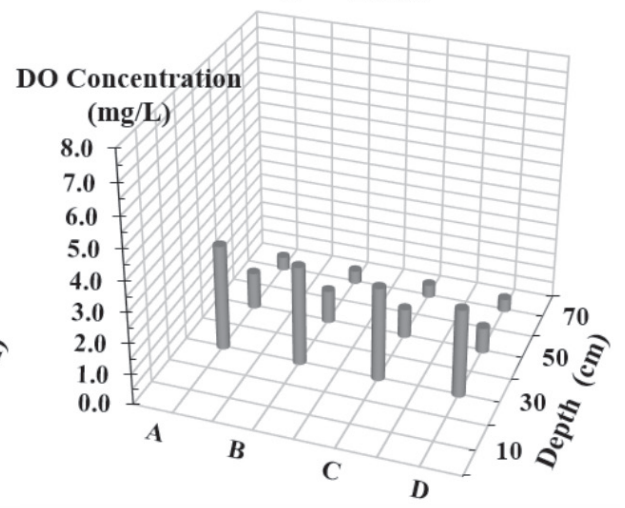

$\mathrm{T}=6.5 \mathrm{~h}$

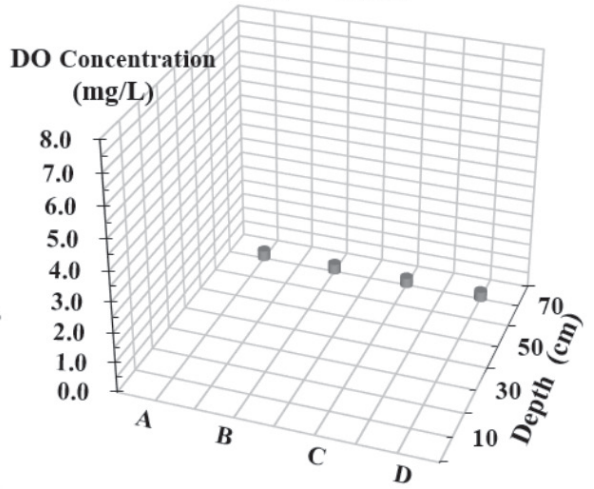

Fig. 5. DO concentration of the plant group in $5^{\circ}$. 
zone entered an anaerobic state, and denitrification increased.

\section{The Concentration Distributions of DO in the Slope-Constructed Wetlands}

Fig. 5 shows the DO concentration variation in the slope-constructed wetlands at $5^{\circ}$. And figures of DO concentration variation at $10^{\circ}$ and $15^{\circ}$ were provided in the appendix (supplementary Fig. 3). DO decreased along the direction of water flow. As the depth increased, the DO content gradually decreased. The reasons were as following: on the one hand, the degradation of pollutants requires the consumption of oxygen; on the other hand, with increasing depth, the lower the reoxygenation capacity of the substrate is [21].

An interesting point is that the value of DO did not decrease with time when the slope was the same. This finding was because in the slope-constructed wetland, on the slope, the high part of the slope already had an unsaturated zone and had a certain reoxygenation restoring capacity that was similar to the DO of pore water in the previous period. The flow pattern of water
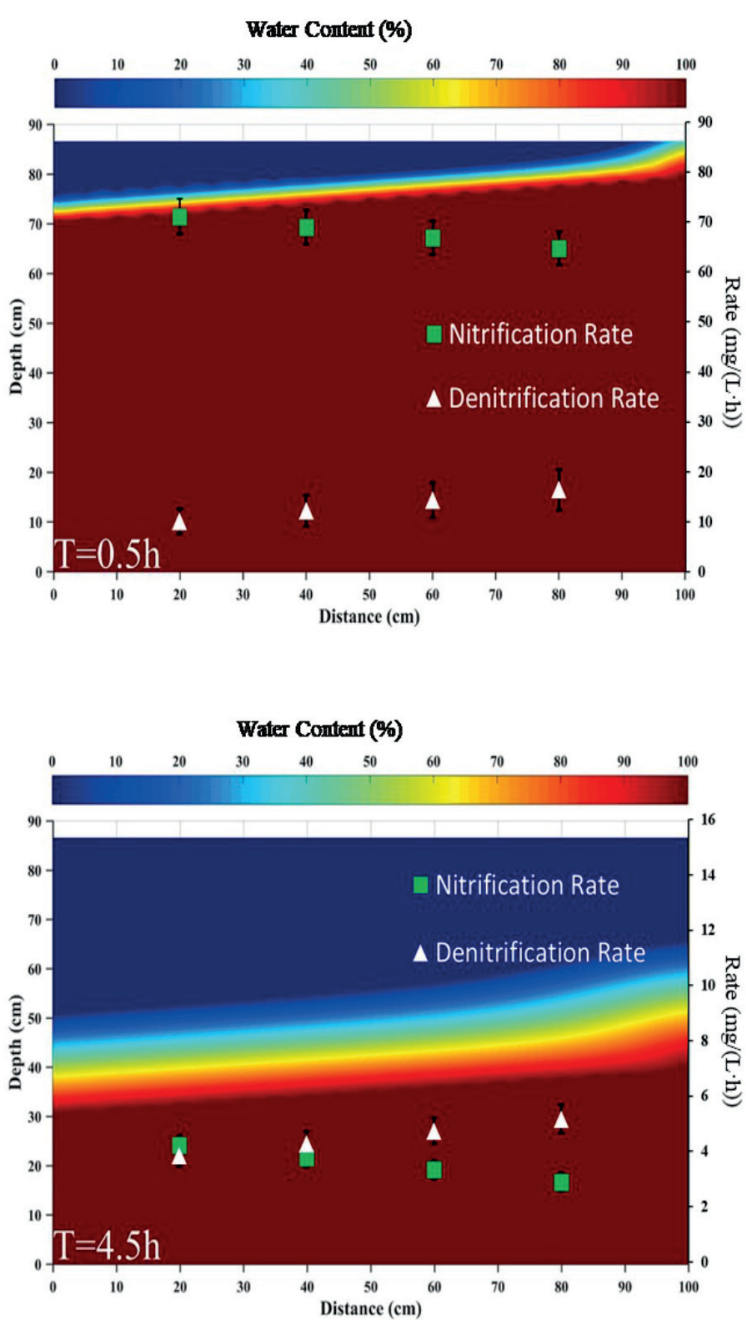

Fig. 6. Water distribution map of the plant group with a slope of $5^{\circ}$. has the characteristics of both horizontal flow and vertical flow.

\section{Variation in the Nitrification Rates and Denitrification Rates with Depth}

As shown in Figs 6, 7 and 8, the nitrification rate at a depth of $10 \mathrm{~cm}$ was approximately $63 \mathrm{mg} /(\mathrm{L} \cdot \mathrm{h})$, and the denitrification rate was approximately $5 \mathrm{mg} /(\mathrm{L} \cdot \mathrm{h})$. Obviously, the rate of nitrification was higher than that of denitrification. Regarding the water content, the nitrification rate was fast in the region with a low water content, while the denitrification rate was slow. This finding was because atmospheric reoxygenation was fast in the region with a low water content, the DO concentration was high, and nitrification was fast. At a depth of $30 \mathrm{~cm}$, the nitrification rate was also higher than the denitrification rate. In addition to the above reasons, it was also possible that the root system at this depth was relatively lush, and the root system secreted more oxygen, leading to the nitrification rate being higher than the denitrification rate. At a depth of $50 \mathrm{~cm}$, the denitrification rate was gradually close to the denitrification rate, and the denitrification rate exceeded
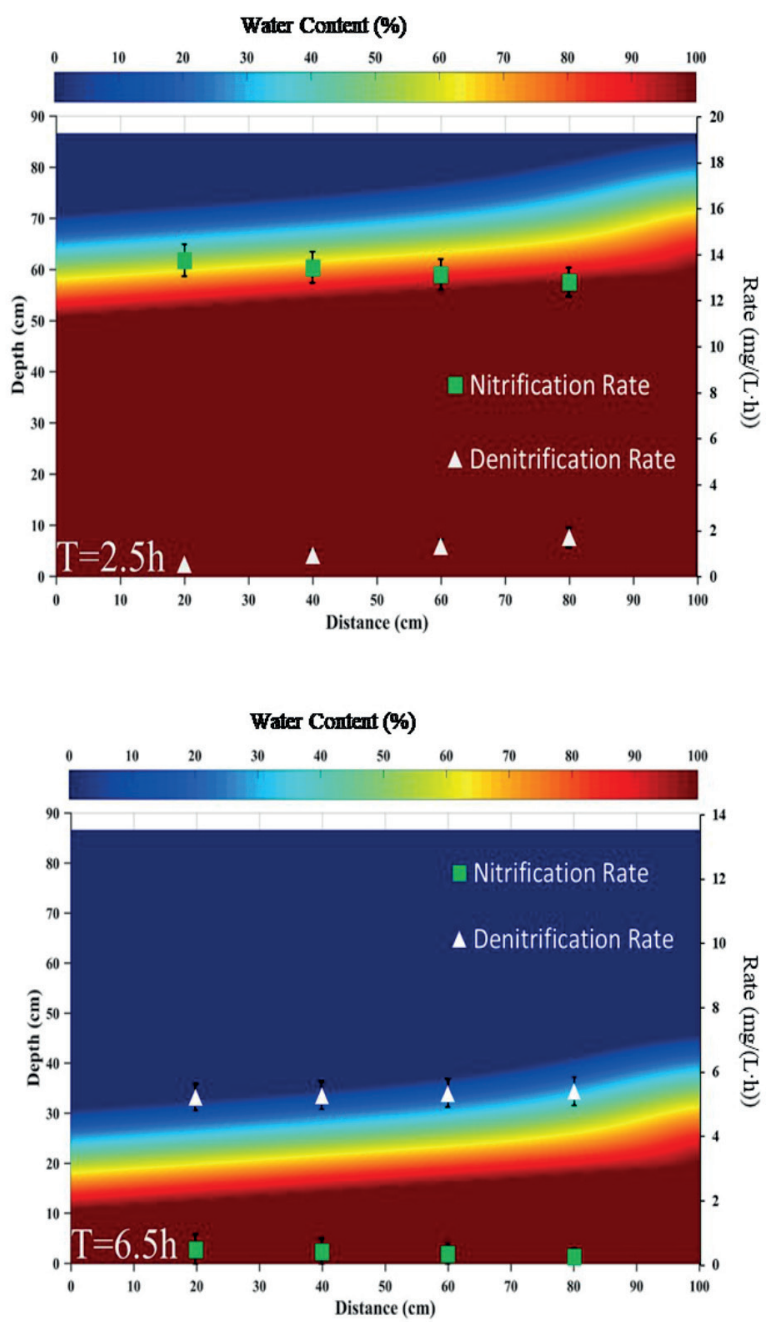

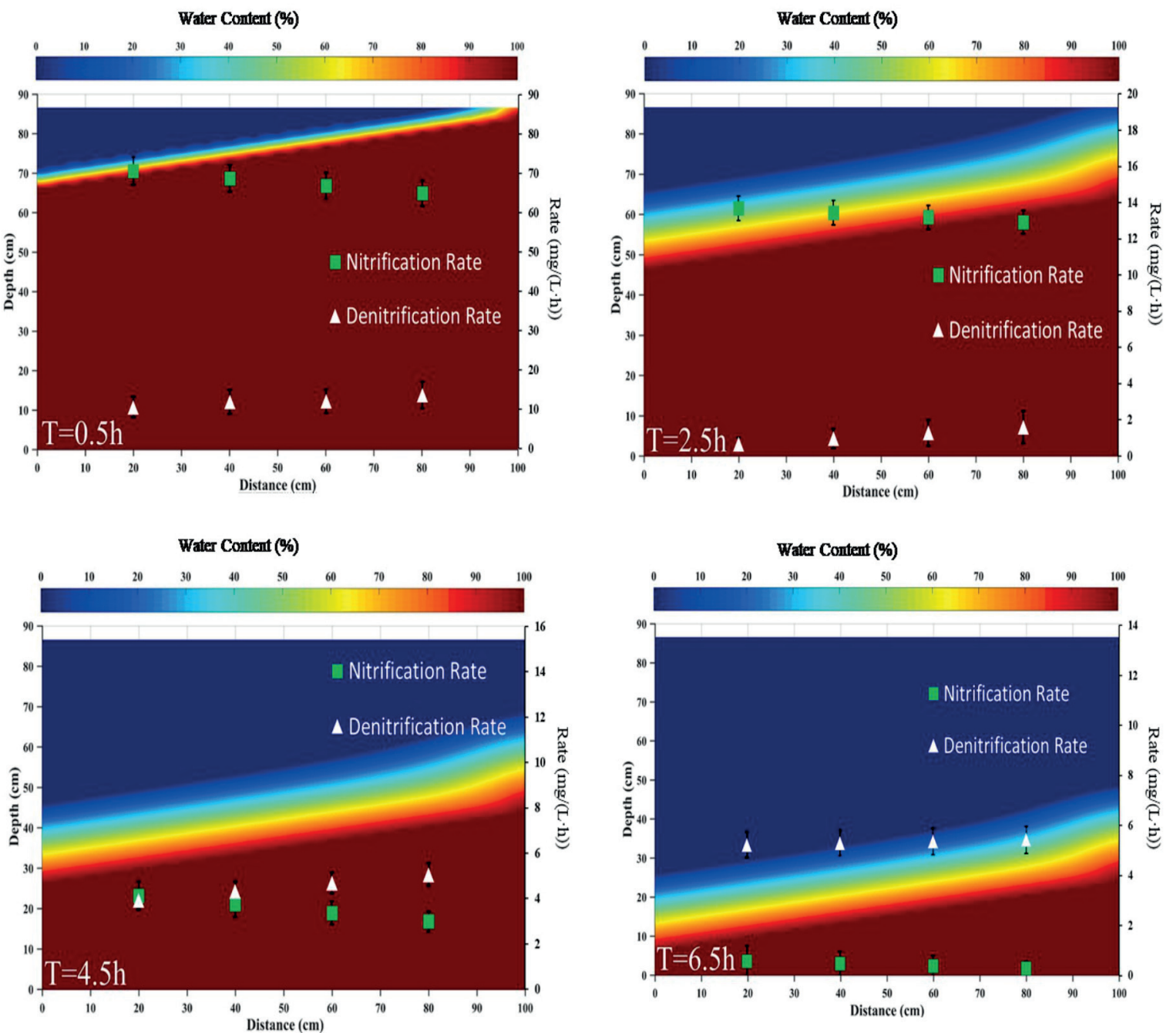

Fig. 7. Water distribution map of the plant group with a slope of $10^{\circ}$.

nitrification rate in reverse. This finding was because the DO concentration in the saturated zone was basically exhausted, and the atmospheric reoxygenation rate also slowed down with increasing depth. In particular, the denitrification rate in the saturated zone was greater than the nitrification rate. At a depth of $70 \mathrm{~cm}$, the denitrification rate was $35 \mathrm{mg} /(\mathrm{L} \cdot \mathrm{h})$, and the nitrification rate was $6 \mathrm{mg} /(\mathrm{L} \cdot \mathrm{h})$. Obviously, the denitrification rate was higher than the nitrification rate. This finding was because at the bottom of the wetland, there was very little dissolved oxygen in the saturated zone, and the environment became anaerobic [22].

By comparing the water distribution maps at each time point when the slope was $5^{\circ}, 10^{\circ}$ and $15^{\circ}$, the water level in the device decreased over time; the nitrification rate also decreased, and the change trend of the nitrification rate and denitrification rate was opposite in the horizontal distance direction. This result may be because the concentration of DO gradually decreased over time, leading to the weakening of nitrification and the strengthening of denitrification. At the same time, according to the analysis, the change in slope conditions had a certain impact on the nitrification rate and denitrification rate. For example, at $\mathrm{T}=0.5 \mathrm{~h}$, with a slope increase, the nitrification rates at points $\mathrm{A}$ and $\mathrm{B}$ also increased, while the nitrification rates at points $\mathrm{C}$ and $\mathrm{D}$ decreased. The specific performance was as follows: the nitrification rates at $\mathrm{A}$ and $\mathrm{B}$ when the slope was $5^{\circ}$ were approximately $0.60-1.00 \mathrm{mg} /(\mathrm{L} \cdot \mathrm{h})$ and $0.20-0.40 \mathrm{mg} /(\mathrm{L} \cdot \mathrm{h})$ lower than those of the other slopes, respectively. At $\mathrm{C}$ and $\mathrm{D}$, they were approximately $0.20-0.40 \mathrm{mg} /(\mathrm{L} \cdot \mathrm{h})$ and $0.60-0.85 \mathrm{mg} /(\mathrm{L} \cdot \mathrm{h})$ higher than those of the other slopes, respectively. The tread of denitrification rates was opposite. The denitrification rates at points $\mathrm{A}$ and $\mathrm{B}$ decreased as the slope increased, and the rates at points $\mathrm{C}$ and $\mathrm{D}$ increased as the slope increased. The specific performance was as follows: the denitrification rates at $\mathrm{A}$ and $\mathrm{B}$ when the slope was $5^{\circ}$ were approximately $0.12-1.00 \mathrm{mg} /(\mathrm{L} \cdot \mathrm{h})$ and $0.03-0.40 \mathrm{mg} /(\mathrm{L} \cdot \mathrm{h})$ higher than those of the other slopes, respectively. At $\mathrm{C}$ and $\mathrm{D}$, they were approximately 0.06-0.20 $\mathrm{mg} /(\mathrm{L} \cdot \mathrm{h})$ and $0.16-0.80 \mathrm{mg} /(\mathrm{L} \cdot \mathrm{h})$ lower than those of the other slopes, respectively. This was consistent with the results of $\mathrm{He}$ et al. [23], which may be because the change in the state of aerobicanaerobic in the matrix led to the change in the number 

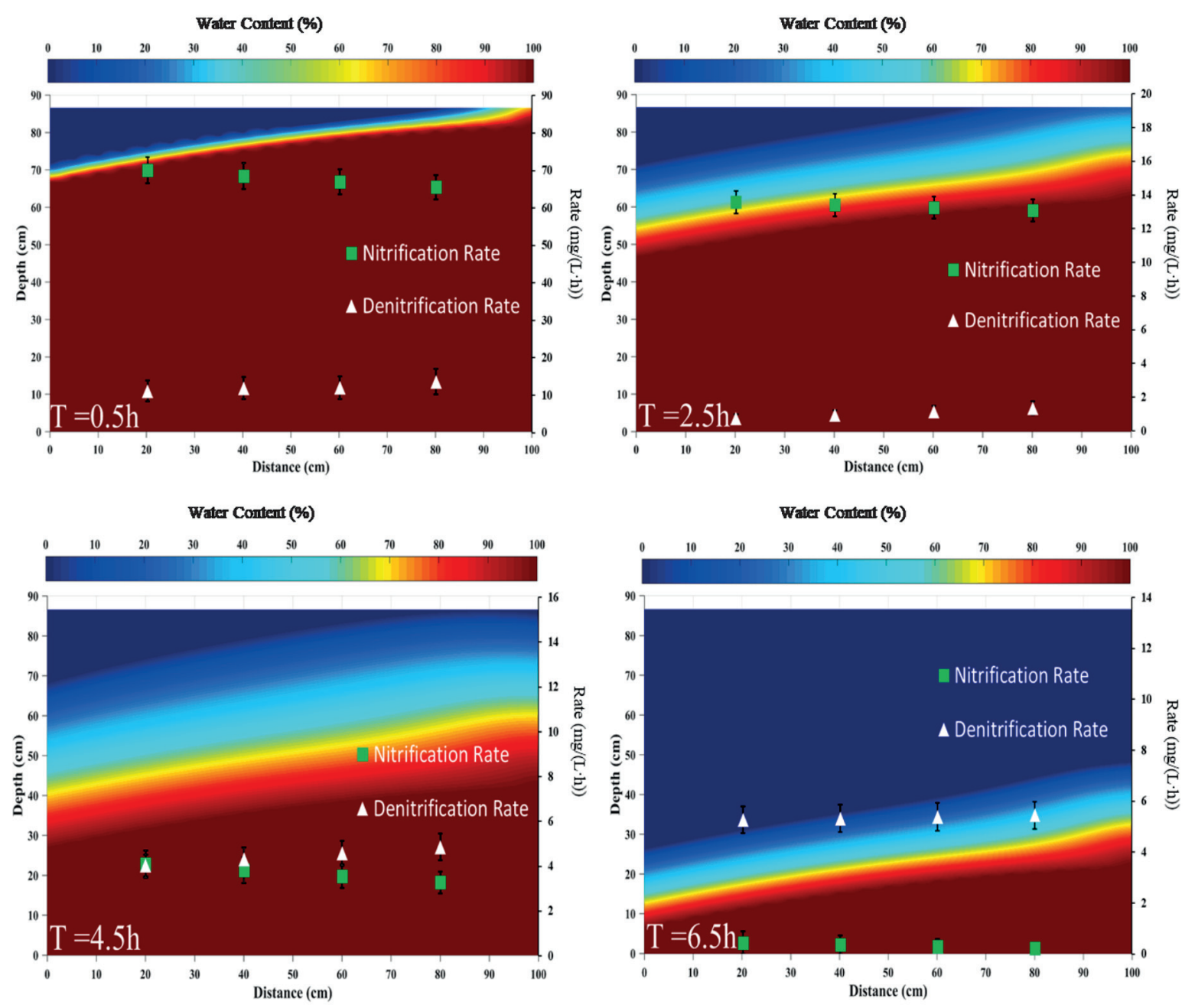

Fig. 8. Water distribution map of the plant group with a slope of $15^{\circ}$.

of nitrifying bacteria and denitrifying bacteria in the matrix, which in turn affected the nitrification rate and nitrification rate in different slopes and along the flow course.

Studies have shown that the number of microorganisms in constructed wetlands has a decreasing trend along the flow direction, which may be caused by the gradual decrease of organic matter concentration, resulting in the gradual decrease of the number of heterotrophic microorganisms [24]. The concentration of organic matters and DO in the front end of the wetland system is high, and the activity of aerobic microorganisms and nitrifying bacteria is the highest. As a result, pollutants are largely degraded in the front end of the wetland system, leading to the decrease of $\mathrm{NH}_{4}^{+}-\mathrm{N}$ concentration. In the back end, due to the limitation of DO concentration, the activities of anaerobic microorganism and denitrifying bacteria were higher, and the denitrification rate was enhanced. As the nitrifying bacteria degrade ammonia nitrogen to nitrate nitrogen at the front end of the wetland, the generated nitrate nitrogen flows with the water flow and is greatly degraded by denitrifying bacteria at the back end of the wetland [25].
Statistical analysis found that under the three slopes, there was no significant difference in nitrification rate and denitrification rate at different time points $(\mathrm{P}>0.05)$. However, under the same slope, the nitrification rate and denitrification rate at different time points have significant differences $(\mathrm{P}<0.05)$. Besides, negative correlations were found between nitrification rate and denitrification rate at $5^{\circ}, 10^{\circ}$ and $15^{\circ}\left(\mathrm{r}_{5}=-0.825\right.$, $\left.\mathrm{r}_{10}=-0.818, \mathrm{r}_{15}=-0.814, \mathrm{P}<0.01\right)$.

\section{The Scaling Diagram of the Saturated and Unsaturated Zones with Different Slopes}

Changes in the water level indicated changes in the proportions of the nitrification and denitrification zones in the saturated and unsaturated zones (Fig. 9). The ratios of the saturated zone and unsaturated zone caused by different slopes were constantly changing, leading to different proportions of the nitrification zone and denitrification zone and finally different effects of nitrogen removal.

The particularity of water flow in slope-constructed wetlands combines the characteristics of horizontal subsurface-constructed wetlands and vertical- 

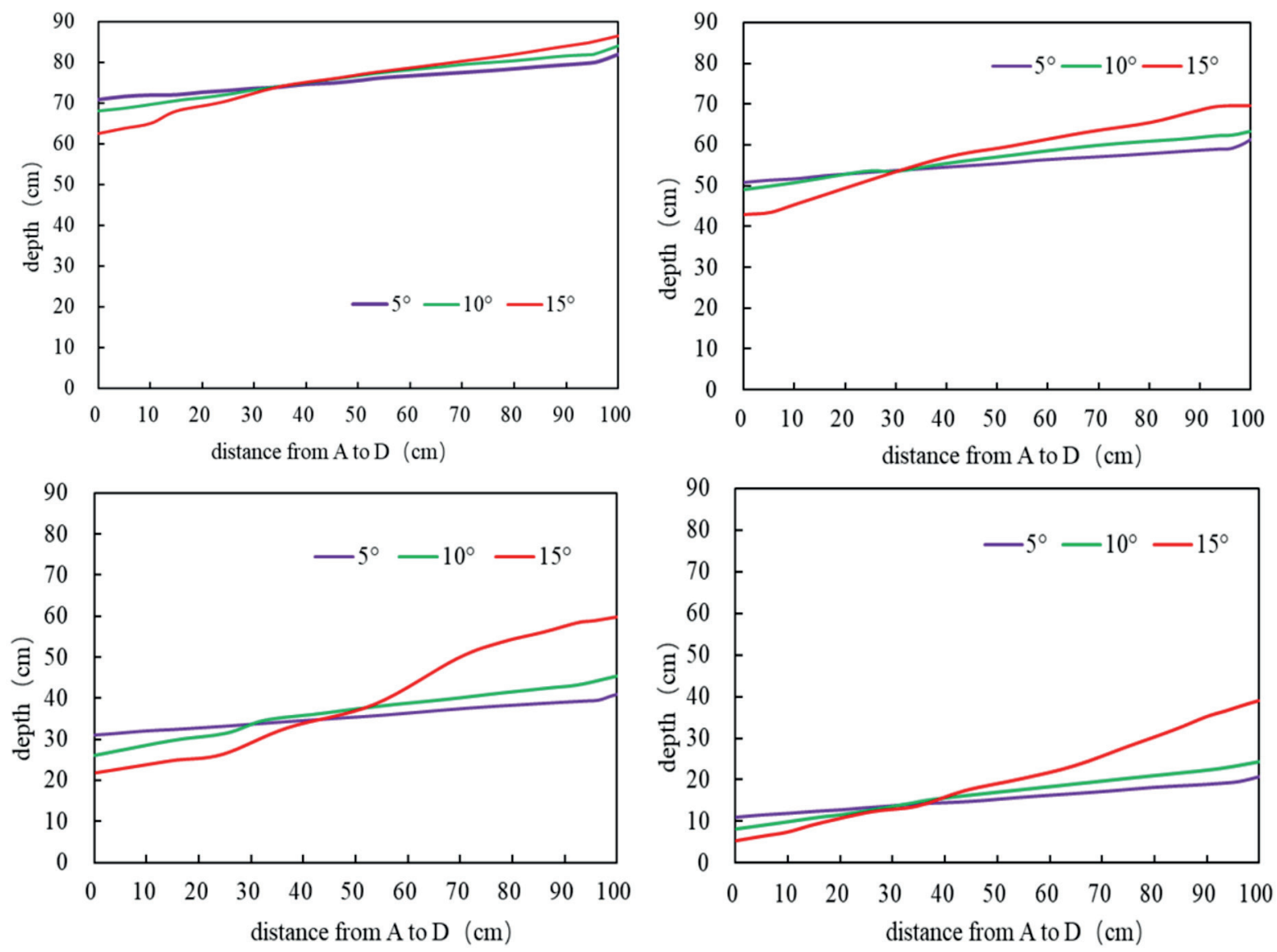

Fig. 9. Variation diagram of the water level.

constructed wetlands. The flow field changes with both slope and depth.

The variation in the saturated zone and unsaturated zone is different from those of horizontal subsurface flow-constructed wetlands and vertical flow-constructed wetlands. The variation in the saturated and unsaturated zones of vertical flow-constructed wetlands and horizontal subsurface-constructed wetlands is only related to the hydraulic load, but the variation in the saturated and unsaturated zones of slope-constructed wetlands is related not only to the hydraulic load but also to the slope gradient. The removal rate of $\mathrm{NH}_{4}^{+}-\mathrm{N}$ mainly occurred in unsaturated zone and was much higher than that in saturated zone while utotrophic denitrification mainly occurred in the saturated area. Nitrification process was associated with autotrophic/heterotrophic ammonia oxidizing bacteria and nitrite oxidizing bacteria. Denitrification process relied on both autotrophic and heterotrophic denitrifiers [26]. The slope and hydraulic load can be adjusted to the proportion of saturated and unsaturated areas, which means that the proportion of nitrification and denitrification areas can be adjusted to specifically remove nitrogen with different forms and to improve the effect of nitrogen removal. This scenario is a special feature of slope-constructed wetlands.

\section{Conclusions}

Slopes had different effects on various forms of nitrogen removal in slope-constructed wetland. The main reason for the different nitrogen removal effects of constructed wetlands with different slopes was the change in the ratio of saturated and unsaturated zones. Alternating aerobic and anaerobic conditions were effectively developed on the constructed slopes. The transformation and removal of nitrogen could be accomplished by nitrification-denitrification. The saturated zone was suitable for removing ammonia nitrogen, while the unsaturated zone was suitable for removing nitrate nitrogen. To effectively remove TN from sewage, an appropriate slope should be selected according to the ratio of ammonia nitrogen and nitrate nitrogen in the inflow.

\section{Acknowledgements}

The authors acknowledge the financial support for this study from the National Key Research and Development Program of China (Grant No. 2018YFC0407506) and the Fundamental Research Funds for the Central Universities (2018B11614). 


\section{Conflict of Interest}

The authors declare no conflict of interest.

\section{References}

1. AZIZ A., BASHEER F., SENGAR A., IRFANULLAH, KHAN S.U., FAROOQI I.H., Biological wastewater treatment (anaerobic-aerobic) technologies for safe discharge of treated slaughterhouse and meat processing wastewater, Science of the Total Environment, 686, 681, 2019.

2. RAMIREZ S., TORREALBA G., LAMEDA-CUICAS E., MOLINA-QUINTERO L., STEFANAKIS A.I., PIRESIERRA M.C., Investigation of pilot-scale constructed wetlands treating simulated pre-treated tannery wastewater under tropical climate, Chemosphere, 234, 496, 2019.

3. WU H.M., ZHANG J., NGO H.H., GUO W.S., HU Z., LING S., FAN J.L., LIU H., A review on the sustainability of constructed wetlands for wastewater treatment: Design and operation, Bioresource Technology, 175, 594, 2015.

4. LI H., CHI Z.F., YAN B.X., CHENG L., LI J.Z., Nitrogen removal in wood chip combined substrate baffled subsurface- flow constructed wetlands: impact of matrix arrangement and intermittent aeration, Environmental Science and Pollution Research International, 24, 5032, 2017.

5. FAN G.D., LI Z.S., WANG S.M., HUANG K.S., LUO J., Migration and transformation of nitrogen in bioretention system during rainfall runoff, Chemosphere, 232, 54, 2019.

6. LI H.Y., TAO W.D., Efficient ammonia removal in recirculating vertical flow constructed wetlands: Complementary roles of anammox and denitrification in simultaneous nitritation, anammox and denitrification process, Chemical Engineering Journal, 317, 972, 2017.

7. BOOG J., NIVALA J., AUBRON T., WALLACE S., AFFERDEN M.V., ARON MULlERA R., Hydraulic characterization and optimization of total nitrogen removal in an aerated vertical subsurface flow treatment wetland, Bioresource Technology, 162, 166, 2014.

8. FAN J.L., ZHANG B., ZHANG J., NGO H.H., GUO W.S., LIU F.F., GUO Y.Y., WU H.M., Intermittent aeration strategy to enhance organics and nitrogen removal in subsurface flow constructed wetlands, Bioresource Technology, 141, 117, 2013.

9. FAN J.L., LIANG S., ZHANG B., ZHANG J., Enhanced organics and nitrogen removal in batch-operated vertical flow constructed wetlands by combination of intermittent aeration and step feeding strategy, Environmental Science and Pollution Research International, 20, 2448, 2013.

10. HUANG L., WANG N., DENG C.R., LIANG Y.K., WANG Q.H., LIU M.L., CHEN Y.C., Interactive effect of carbon source with influent $\mathrm{COD} / \mathrm{N}$ on nitrogen removal and microbial community structure in subsurface flow constructed wetlands, Journal of Environmental Management, 250, 109491, 2019.

11. ROUS V., VYMAZAL J., HNATKOVA T., Treatment wetlands aeration efficiency: A review, Ecological Engineering, 136, 62, 2019.

12. HUANG M.L., WANG Z., QI R., Enhancement of the complete autotrophic nitrogen removal over nitrite process in a modified single-stage subsurface vertical flow constructed wetland: Effect of saturated zone depth, Bioresource Technology, 233, 191, 2017.

13. WU S.B., KUSCHK P., BRIX H., VYMAZAL J., DONG R.J., Development of constructed wetlands in performance intensifications for wastewater treatment: A nitrogen and organic matter targeted review, Water Research, 57, 40, 2014.

14. SUN Y.F., PAN J., QI S.Y., FEI H.X., Effects of hydraulic loading rate and aeration mode on nitrogen removal and nitrogen functional gene abundances in subsurface wastewater infiltration systems, Water Science and Technology, 76 (1), 210, 2017.

15. HU Y.S., ZHAO Y.Q., ZHAO X.H., KUMAR J.L.G., Comprehensive analysis of step-feeding strategy to enhance biological nitrogen removal in alum sludge-based tidal flow constructed wetlands, Bioresource Technology, 111 (5), 27, 2012.

16. LIAO K.H., LU L.G., YANG G.S., ZHU Q., Sensitivity of simulated hillslope subsurface flow to rainfall patterns, soil texture and land use, Soil Use and Management, 32, 422, 2016

17. GONZALO O.G., RUIZ I., SOYO M., Integrating pretreatment and denitrification in constructed wetland systems, Science of the Total Environment, 584-585, 1300, 2017.

18. TANNER C.C., SUKIAS J.P.S., HEADLEY T.R., YATES C.R., STOTT R., Constructed wetlands and denitrifying bioreactors for on-site and decentralised wastewater treatment: Comparison of five alternative configurations, Ecological Engineering, 42 (5), 112, 2012.

19. RAO S.M., MALINI R., Role of degree of saturation in denitrification of unsaturated sand specimens, Environmental Earth Sciences, 72, 4371, 2014.

20. SAEED T., SUN G.Z., Pollutant removals employing unsaturated and partially saturated vertical flow wetlands: A comparative study, Chemical Engineering Journal, 325, 332,2017

21. LI X., LI Y.Y., LI Y., WU J.S., Enhanced nitrogen removal and quantitative analysis of removal mechanism in multistage surface flow constructed wetlands for the large-scale treatment of swine wastewater, Journal of Environmental Management, 246, 575, 2019.

22. WU S.B., WALLACE S., BRIX H., KUSCHK P., KIRUI W.K., MASI F., DONG R.J., Treatment of industrial effluents in constructed wetlands: Challenges, operational strategies and overall performance, Environmental Pollution, 201, 1070, 2015.

23. HE F., WU Z.B., TAO J., CHENG S.P., FU G.P., Nitrification and Denitrification in the Integrated Vertical Flow Constructed Wet-lands, Environmental Science, 01, 47, 2005.

24. SHANG X.L., Study on microorganism distribution and removing correlation in different types of constructed wetlands, Harbin Institute of Technology, 2012.

25. GUO S.L., Effects of water-level change on Nitrogen Transfer and migration in horizontal subsurface flow constructed wetlands, Donghua University, 2017.

26. XIA Z.G., LIU G.C., SHE Z.L., GAO M.C., ZHAO Y.G., GUO L., JIN C.J., Performance and bacterial communities in unsaturated and saturated zones of a vertical-flow constructed wetland with continuous-feed, Bioresource Technology, 315, 123859, 2020. 